\title{
IMPACT OF ACQUISITION ANNOUNCEMENT ON STOCK RETUNS
}

\author{
Lavita Fernandes \\ II MBA, AIET, \\ Mijar, Moodbidri- 574225 \\ Email: lavitaf021@gmail.com \\ Dr. Kushalappa. S \\ Senior Assistant Professor \\ Department of MBA \\ AIET, Mijar, Moodbidri 574225 \\ Email: kushalkayarthadka@gmail.com
}

\begin{abstract}
With increased industrialization and development, it is essential for companies to gain a positive image in the eyes of the various potential investors. One way of achieving this is by registering positive stock performance. In order to obtain and retain a positive image on the investors, company managers perform comprehensive planning and create effective strategies in order to increase the value of the company's stocks. A few of these strategies include mergers and acquisitions. Mergers and acquisition is a method for enterprises to develop and increase their assets and their financial values. Most of the economic sectors witnessed a large number of mergers and acquisitions. Multinational enterprises start taking place in energy sector, willing to add financial values and improve their market position. Local energy firms tried to expand, but high competition didn't allow them to develop as much as they expected. Big players acquired a lot of "small" companies trying to enter new markets and expand. This paper uses an Event Study Methodology to test whether an M\&A have an impact on a firms' stock price, and to investigate the informational value for $M \& A$ announcements to the shareholders to earn abnormal returns. The focus of this paper is to examine the effect of Acquisition announcements on Indian Stock Market. An attempt is made here to compare the reaction of capital market during post-merger announcement period and pre-merger announcement period.
\end{abstract}

KEY WORDS: Acquisition, announcement, merger, stock return.

\section{INTRODUCTION:}

With increased industrialization and development, it is essential for companies to gain a positive image in the eyes of the various potential investors. One way of achieving this is by registering positive stock performance. In order to obtain and retain a positive image on the investors, company managers perform comprehensive planning and create effective strategies in order to increase the value of the company's stocks. A few of these strategies include mergers and acquisitions. Mergers and acquisition is a method for enterprises to develop and increase their assets and their financial values. Most of the economic sectors witnessed a large number of mergers and acquisitions. Multinational enterprises start taking place in energy sector, willing to add financial values and improve their market position. Local energy firms tried to expand, but high competition didn't allow them to develop as much as they expected. Big players acquired a lot of "small" companies trying to enter new markets and expand. This paper uses an Event Study Methodology to test whether an M\&A have an impact on a firms' stock price, and to investigate the informational value for M\&A announcements to the shareholders to earn abnormal returns. The focus of this paper is to examine the effect of acquisition announcements on Indian Stock Market. An attempt is made here to compare the reaction of capital market during post-merger announcement period and pre-merger announcement period.

\section{OBJECTIVES:}

To study the impact of Acquisition Announcement on stock market 
i. To identify Changes in the performance of companies

ii. To compare the performance of acquiring companies in the stock market before and after acquisition announcement.

iii. To offer meaningful suggestions to the investors based on the study

\section{SCOPE OF THE STUDY:}

The study examines the reaction of capital market for acquisition announcement. The study period is 2013 - 14. The study covers only five acquired companies and one acquisition announcement of each company is covered.

\section{METHODOLOGY:}

In this study data have taken on the acquisition announcements made by acquiring companies included in the BSE SENSEX index from 2004 to 2014. The effects of aqisition announcements of the companies on equity share prices was examined by taking daily adjusted market price data for the sample stocks 15 days before and 15 days after the merger announcement date. The study is purely based on secondary data extracted from various sources like books and websites. The sample size is Five acquiring companies selected randomly.

\section{Techniques of analysis:}

Daily returns for each sample company has been computed for the estimation period and also for the event period as

$\mathrm{R}_{\mathrm{it}}=\frac{M P_{i t}-M P_{i(1-t)}}{M P_{i(1-t)}}$

Where, $\mathrm{MP}_{\mathrm{it}}=$ Market price (closing) of security ' $\mathrm{i}$ ' on day $\mathrm{t}$ and $\mathrm{MP}_{\mathrm{i}(1-\mathrm{t})}=$ Market price of security on day ( $\mathrm{t}-1)$.

\section{Limitations}

Every research has its own limitations. The following are the limitations of this study.

$>$ The study covers only few companies which are taken for the studying the impact of acquisition.

$>$ This study is restricted only to Indian companies.

\section{ANALYSIS AND INTERPRETATION}

This part of the study deals with the analysis of the data collected on the topic of research.

Table 1: Returns before Acquisition announcement

\begin{tabular}{|c|c|c|c|c|c|}
\hline Days/Co. & Sun pharma & TCS & Jindhal steel & Fortis GHC & Tata steel \\
\hline-1 & -2.20178372 & -7.0180538 & 0.14392631 & 2.02742993 & 1.972983 \\
\hline-2 & 6.21669627 & -5.7155907 & -1.836677027 & 2.28728271 & 5.774247 \\
\hline-3 & 3.113553114 & -2.1162444 & 0.539772727 & -0.6062443 & 3.628747 \\
\hline-4 & -0.69718096 & 1.2432857 & -0.845070423 & 2.45341615 & -1.402329 \\
\hline-5 & -3.16994423 & 6.9554272 & -1.662049861 & -0.6785935 & 0.771911 \\
\hline-6 & 4.830769231 & -8.3966532 & -5.497382199 & 2.59493671 & -1.672655 \\
\hline-7 & -0.36787247 & -1.9907273 & -4.260651629 & -1.0644959 & -1.704944 \\
\hline-8 & 1.810237203 & -3.2601688 & -1.481481481 & -1.3893177 & 0.321438 \\
\hline-9 & 1.520912548 & -1.0128198 & -0.135618296 & -0.6746397 & -0.710525 \\
\hline
\end{tabular}


Asia Pacific Journals

\begin{tabular}{|c|c|c|c|c|c|}
\hline-10 & -0.81709617 & -5.9060052 & 0.732737208 & -0.3057169 & 3.914401 \\
\hline-11 & 1.628872565 & 0 & 0.624843789 & 0.55333538 & 1.257476 \\
\hline-12 & 0.675241158 & 6.3741147 & -4.499343597 & -0.1841056 & 2.043573 \\
\hline-13 & 1.733725875 & -1.1937431 & 0.395398994 & -2.220222 & -0.776829 \\
\hline-14 & 0.559210526 & -2.7696248 & -0.095762509 & -0.4480287 & -1.693261 \\
\hline-15 & -1.39474538 & -1.6067209 & 2.465350178 & 0.96501809 & -1.045414 \\
\hline Average & $\mathbf{0 . 8 9 6 0 4}$ & $\mathbf{- 1 . 7 6 0 9}$ & $\mathbf{- 1 . 0 2 7 4 7}$ & $\mathbf{0 . 2 2 0 6 7}$ & $\mathbf{0 . 7 1 1 9 2 1}$ \\
\hline
\end{tabular}

\section{Source: Authors Compilation}

It is found in Table 1 that among the companies under study, sun pharma, Tata steel, and Fortis global health care have positive returns and TCS and Jindhal steel have negative returns. During preacquisition period, sun pharma has the highest return compared to all other stocks.
It is found in Table 2 that during among the companies comes under post acquisition Jindal steel, sun pharma and TCS and Tata steel have positive returns and only Fortis GHS has negative average return. Among the companies under study, Jindal Steel has the highest return, during after the acquisition announcement period.

Table 2: Returns after acquisition announcements

\begin{tabular}{|c|c|c|c|c|c|}
\hline Days/Co. & Sun pharma & TCS & Jindhal steel & Fortis GHC & Tata steel \\
\hline 1 & -0.45909 & -0.92903 & 1.372151 & 2.341555 & 0.679732 \\
\hline 2 & -1.38482 & 0.370028 & -6.14782 & -1.14198 & 0.196366 \\
\hline 3 & 2.038043 & 8.752515 & 4.32243 & -1.51976 & 2.488918 \\
\hline 4 & 1.826231 & 1.387189 & 7.537688 & -0.60423 & 0.06883 \\
\hline 5 & 1.802817 & -10.4592 & 0.759494 & 0.730371 & 0.394134 \\
\hline 6 & -1.98785 & 0.201332 & 0.381194 & 0.489297 & 0.729569 \\
\hline 7 & 1.884669 & -2.62698 & 4.626429 & -0.87905 & 1.539186 \\
\hline 8 & -0.14045 & 12.86105 & 8.386167 & -0.93093 & -2.59313 \\
\hline 9 & 0.764223 & 9.468029 & 0.638051 & -0.2994 & -2.09446 \\
\hline 10 & 0.22695 & -8.28756 & 2.925373 & 0.059916 & -1.809 \\
\hline 11 & -5.64775 & -8.6448 & -2.27538 & -1.15487 & -0.58243 \\
\hline 12 & -0.77025 & -8.46055 & 0 & -0.29525 & -0.19215 \\
\hline 13 & 2.309783 & 2.841264 & -1.692 & -1.93978 & -1.00169 \\
\hline 14 & 1.405346 & 10.0956 & -0.37143 & 1.260627 & 1.500635 \\
\hline 15 & 3.656098 & -4.3176 & 3.550296 & -1.58684 & 1.137038 \\
\hline Average & $\mathbf{0 . 3 6 8 2 6 3}$ & $\mathbf{0 . 1 5 0 0 8 6}$ & $\mathbf{1 . 6 0 0 8 4 3}$ & $\mathbf{- 0 . 3 6 4 6 9}$ & $\mathbf{0 . 0 3 0 7 7}$ \\
\hline
\end{tabular}


Table 3: Average returns before acquisition announcement and after acquisition announcement

\begin{tabular}{|c|c|c|}
\hline Days/Co. & $\begin{array}{c}\text { Average returns before acquisition } \\
\text { announcement }\end{array}$ & $\begin{array}{c}\text { Average returns after acquisition } \\
\text { announcement }\end{array}$ \\
\hline 1 & -1.01258 & 0.601064 \\
\hline 2 & 0.78766 & -1.62165 \\
\hline 3 & 0.259931 & 3.216429 \\
\hline 4 & -0.54131 & 2.043142 \\
\hline 5 & -0.46387 & -1.35448 \\
\hline 6 & -2.35683 & -0.03729 \\
\hline 7 & -2.73145 & 0.908851 \\
\hline 8 & -1.99988 & 3.516541 \\
\hline 9 & -1.66878 & 1.695289 \\
\hline 10 & -2.06361 & -1.37686 \\
\hline 11 & -1.15591 & -3.66105 \\
\hline 12 & -1.26509 & -1.94364 \\
\hline 13 & -2.51028 & 0.103515 \\
\hline 14 & -3.07458 & 2.778156 \\
\hline 15 & -2.60275 & 0.487798 \\
\hline Average & $\mathbf{- 1 . 4 9 3 2 9}$ & $\mathbf{0 . 3 5 7 0 5 5}$ \\
\hline
\end{tabular}

\section{Source: Authors compilation}

Table 3 shows the fact that returns before the acquisition announcement is negative and returns after acquisition announcement is positive and therefore the acquisition announcement of the companies under study induced the investors to buy the stocks and therefore market has reacted positively.

Table 4: Correlation of co efficiency between post-merger and pre-merger acquisition

\begin{tabular}{|c|c|c|}
\hline Days/Co. & $\begin{array}{c}\text { Coefficient of variance of returns } \\
\text { before announcement } \\
(\boldsymbol{\%})\end{array}$ & $\begin{array}{c}\text { Coefficient of variance of returns } \\
\text { before announcement }(\boldsymbol{\%})\end{array}$ \\
\hline Sun pharma & 282.6221 & 282.6221 \\
\hline TCS & 246.1945 & 5018.426 \\
\hline Jindhal steel & 216.5837 & 235.4766 \\
\hline Fortis GHC & 687.3232 & 321.6456 \\
\hline Tata steel & 330.1002 & 4681.485 \\
\hline Average & $\mathbf{3 5 2 . 5 6 4 7}$ & $\mathbf{2 1 0 7 . 9 3 1}$ \\
\hline
\end{tabular}


It is clear from the above table that the variance in the return is high during postacquisition announcement period than the pre-acquisition announcement period.

\section{FINDINGS OD THE STUDY:}

Capital market may react positively or negatively for every information. One such publicly available information is acquisition announcement. The aim of this study is to identify the reaction of capital market during acquisition announcement. It is found in the study that during preacquisition announcement period, Sun Pharma has the highest return compared to all other stocks. During postannouncement period, Jindal Steel has the highest return. One of the important findings of the study is that the returns during pre-acquisition announcement are much lesser than returns during postmerger announcement period. It clear indicates that the investors are motivated by the acquisition announcement of the company. Acquisition indicates the growth of the acquired company and it also indicates that a company with high performance and growth opportunities would go for acquiring other companies. This is the reason; people are interested in the stocks of the acquired companies.

\section{CONCLUSION:}

This paper examines whether firms involved in M\&A activities experience favourable return during $\mathrm{M} \& \mathrm{~A}$ announcement periods and tests if average return on the stock holdings of these firms would be affected by the $t$ acquisition, the modes of payment or the types of target companies by using the data of five companies. We find that there exists significantly positive average return for target firms around the Acquisition announcement period. This indicates that market reaction of target firms to takeovers is positive. Thus we can conclude that the terms and conditions of the takeovers are in favour to the shareholders of target firms.

\section{BIBLIOGRAPHY}

[1] Balla V. K. (2002), Portfolio Analysis and Management, Sulthan Chand and Co. Ltd., New Delhi.

[2] BhatSudhindra (2008), Security Analysis and Portfolio Management, Excel Books, New Delhi.

[3] Booie.Zvi, Kane Alex and et.al.(2006), Investments, $6^{\text {th }}$ edition, Tata McGraw Hill, New Delhi.

[4] Chandra Prasanna (2008), Investment Analysis and Portfolio Management, $3^{\text {rd }}$ edition, Tata McGraw Hill, New Dehi.

[5] Fisher. E. Donald and Jordan. J. Ronald (2006), Security Analysis and Portfolio Management, Pearson Prentice Hall.

[6] http://www.nseindia.com/products/ content/equities/equities/eq_securit y.htm

[7] http://www.rbi.org.in/scripts/BS_V iewBulletin.aspx? $\mathrm{Id}=15232$

[8] Kevin. S (2008), Portfolio Management, $2^{\text {rd }}$ edition, PHI Learning Pvt. Ltd, New Delhi.

[9] PandianPunithavathy (2004), Security Analysis and Portfolio 
Management, Vikas Publishing

House Pvt. Ltd, New Delhi.

[10] Reilly. K. Frank and Brown. C.

Keith (2006), Investment Analysis

and Portfolio Management, $8^{\text {rd }}$

edition, Cengage Learning India

Pvt. Ltd, New Delhi. 